Most non-English-speaking countries aspiring to keep abreast with a rapidly globalizing world have made English the first foreign language in their schools. For instance, English is taught from primary level upward at Dutch, Chinese, and Indian schools. In China, the demand for English competency is surging, particularly among upper tier higher education institutions. Malaysia's ASEAN neighbor and competitor, Vietnam, has identified English-medium education as key to improving the quality of its rapidly expanding tertiary institutions. In addition, Vietnam states that English is crucial to its larger aim of modernizing and internationalizing the economy. The Indian National Knowledge Commission of 2009 emphasized that "an understanding and command over the English language is the most important determinant of access to higher education, employment possibilities, and social opportunities. School leavers who are not adequately trained in English as a language are always at a handicap in the world of higher education." English is a key requirement to secure social mobility and high-wage employment in highly competitive areas such as commerce, finance, trade, technology, and science, among others. The British Council reckons that English is spoken at a working level by some I.75 billion people, a quarter of the world's population.

Malaysia's effort to develop into a modern, technological savvy, and export-driven nation depends on strengthening its human capital. Competency in the English language guarantees access to the latest scientific discoveries and developments.

DOI: http://dx.doi.org/10.6oI7/ihe.2019.96.10776

\section{International Faculty in Japan}

\section{FUtAo HUANG}

Futao Huang is professor at the Research Institute for Higher Education, Hiroshima University, Japan. E-mail: futao@hiroshima-u.ac.jp.

S ince the 1980s, hiring international faculty has been used by national higher education systems across the world as an effective strategy to improve their universities' standing in global rankings and their international competitiveness. Accordingly, and as a result of new global and national contextual factors, the profile of international faculty has undergone tremendous changes in terms of work roles as well as perceptions of internationalization of higher education in their host countries. Japan is no exception.

Unlike in other East Asian countries, international faculty have a historic role in Japanese higher education. As early as the late nineteenth century, Japan invited a large number of foreign experts, scholars, and professionals from the United Kingdom, the United States, Germany, and France in an effort to establish a modern society and higher education system based on Western models. PostWWII, the introduction of the US general education ideal to Japanese universities required them to hire international faculty, especially from English-speaking countries, to provide foreign language programs to Japanese students. Subsequently, the implementation of the I982 act for "Employing Foreign Full-time Faculty at National and Local Public Universities" made it possible for public sector institutions to employ international faculty full-time and with tenure, and allowed them to be involved in administrative matters at their institutions. In recent years, recruiting international faculty has also been used as an effective way to enhance the quality and international competitiveness of Japanese higher education. These factors have contributed to a rise in the number of international faculty at Japanese universities: national statistics show that the number of full-time international faculty increased from 940 (0.9 percent of all faculty) in 1979 to 8,262 (4.5 percent of all faculty) in 2017 . In light of this significant increase, this article analyzes the changes that occurred in their personal and professional profiles, in their motivations for coming to work to Japan, and in their perceptions of the labor market, based on a comparison of findings from national surveys conducted in I979 by Professor Kazuhiro Kitamura and in 2017 by the author.

\section{More Asians and More Women in the Hard Sciences}

In terms of country of origin, the first survey shows that in I979, international faculty came predominantly from the United States (39.I percent), followed by the United Kingdom (I7.I percent), Germany (I5 percent), Spain (7.7 percent), France ( 6.6 percent), China (4.4 percent), and South Korea (2.7 percent). By contrast, the second survey shows that in 20I7, the largest groups came from China (22.2 percent), followed by the United States (I8.8 percent), South Korea (13.2 percent), the United Kingdom (8.2 percent), Canada (4.8 percent), Germany (3.8 percent), Australia (2.8 percent), France (I. 8 percent), and Taiwan (I.7 percent). In terms of gender, the number of female faculty increased from 20.7 percent in 1979 to 26.4 percent in 2017 . In terms of disciplines, in I979, the subject areas of international faculty in Japan were mostly languages (33.4 percent), followed language and literature (26.I percent), and literature (I7.4 percent). In 20I7, while the humanities were still the most 
common discipline areas of foreign faculty (39.4 percent), the natural sciences constituted the second largest group (25.5 percent), followed by the social sciences (I8.2 percent) and life sciences (7.3 percent). As for academic rank, in I979, foreign lecturers who solely taught language teaching programs were the most numerous (34.9 percent), followed by professors (23.7 percent), lecturers (I5.8 percent), associate professors (I4.7 percent), guest professors ( 9 percent), and assistant professors ( 0.8 percent). Because of a rapid decline in the numbers of foreign lecturers, in $20 \mathrm{I7}$ the largest proportion of international faculty were professors (35.6 percent), followed by associate professors (29.6 percent), assistant professors (I8.I percent), and lecturers (I3.6 percent).

\section{As early as the late nineteenth century, Japan invited a large number of foreign experts, scholars, and professionals.}

\section{Motivations and Recruitment}

As for their motivations for coming to Japan, in both surveys the largest numbers of respondents stated that they were attracted to Japanese universities for academic or professional reasons (64.9 percent in I979 and 78.9 percent in 20I7), while a significant and growing proportion expressed having an affinity with Japanese life and culture (3I percent in 1979 and 64.8 percent in 2017 ). In 2017 , the majority stated that they had decided to teach or do research in Japan due to better living conditions there than in their home country (37.7 percent, against only I.9 percent in I979), as a result of fortuitous circumstances (29.3 percent, against I4.9 percent in I979), or because of difficulties finding employment in their home country (2I.2 percent against 4.6 percent in I979).

Significant differences could be identified in terms of how these faculty had been recruited. According to the I979 survey, the majority were hired through personal contacts (58.7 percent), through an intermediate agency (I6.I percent), or by applying directly to the institution through the public or international advertisement of a position $(8.5$ percent). In contrast, the 2017 data indicates that as many as 64.7 percent applied directly to the institution, followed by hiring through personal contacts (30.5 percent), and through an intermediate agency ( 0.8 percent). On the one hand, international faculty have become more successful in applying through public or international advertisements.
On the other hand, there is evidence that the Japanese academic market has become increasingly open to international faculty, accepting direct applications from international faculty without relying on personal networking.

This is also supported by the respondents. For example, as many as 7I.7 percent of international faculty in I979 believed that the Japanese academic market was closed to international candidates, while in the 2017 survey only 37.4 percent held such views. Further, they seem to "matter more" in their academic environment. In the I979 survey, nearly half of the respondents (47.5 percent) answered that in general, Japanese faculty were indifferent to their international colleagues, compared to 36 percent in 2017 .

\section{CONCLUSION}

The two surveys demonstrate that considerable changes have occurred in the profiles, recruitment pathways, and perceptions of international faculty in Japan. Japanese universities are attracting significantly more international faculty from neighboring countries than 30 years ago, and have become more of a regional hub. In addition, it appears that international faculty are now playing work roles that are similar to local faculty, rather than predominantly engaging in language teaching as the majority did in the late I970s. However, there are no significant changes in their motivations for coming to Japan.

DOI: http://dx.doi.org/Io.6oI7/ihe.20I9.96.10777

\section{The International Baccalaureate in Japan}

\section{YUKIKO ISHIKURA}

Yukiko Ishikura is lecturer at the Center for the Study of Higher Education and Global Admissions (CHEGA), Osaka University, Japan. Email: ishikura@chega.osaka-u.ac.jp.

The research work leading to this article was supported by JSPS KAKENHI Grant Number JP40762414.

The International Baccalaureate (IB) offers internation$\perp$ ally recognized programs that prepare students to think and act critically and independently as internationally competent individuals. In recent years, the IB has undergone a rapid expansion worldwide. According to the IB Organization, the number of IB programs across the globe increased by 39.3 percent between 2012 and 2017 , as more educational systems have recognized the value of nurturing globally prepared citizens. This trend is manifest in Japan, which 